\title{
NOTE ON SOME INEQUALITIES FOR GENERALIZED CONVEX FUNCTIONS
}

\author{
M. KLARIČIĆ BAKULA AND J. PEČARIĆ
}

Abstract. We give several Jensen's type inequalities for functions convex with respect to a Tchebycheff system $\left\{\omega_{1}, \omega_{2}\right\}$. Results of Bessenyei and Páles from [1] are generalized.

Mathematics subject classification (2000): 26A51, 26B25.

Key words and phrases: generalized convexity, Jensen's inequality.

\section{REFERENCES}

[1] M. BessenYeI, Z. PÁLES, Hadamard-type inequalities for generalized convex functions. Math. Inequal. Appl., 6, 3 (2003), 379-392.

[2] E. F. BECKENBACH, Generalized convex functions, Bull.Amer.Math.Soc., 43, (1937), 363-371.

[3] J. E. Pečarić, F. Proschan and Y. L. Tong, Convex Functions, Partial Orderings, and Statistical Applications, Academic Press, Inc. (1992).

[4] A. W. Roberts, D. E. VARberg, Convex Functions, Academic Press (1973).

[5] D. S. Mitrinović, J. E. PeČARIĆ AND A. M. FinK, Classical and New Inequalities in Analysis, Kluwer Academic Publishers (1993). 